\title{
Studies on Biohydrogen Production from Rice Mill Waste Water Using Enterobacter aerogenes MTCC 2822 by Dark Fermentation Process
}

\section{Sundaram Haridoss*}

Department of Petroleum Engineering, AMET University, Chennai, India

\begin{abstract}
This study presents the production of biohydrogen from rice mill wastewater by dark fermentation using Enterobacter aerogenes. Physico-chemical characteristics were determined in order to make the biological methods favorable alternatives for the removal of pollutants from the industrial effluent. The wastewater was subjected to acid hydrolysis to produce reducing sugar and the influence of acid concentration was studied. The maximum reducing sugar concentration under optimized condition was $10.3 \mathrm{~g} / \mathrm{L}$ and the gas collected after three days of fermentation was $800 \mathrm{ml}$ and the maximum biomass concentration obtained was $3.15 \mathrm{~g} / \mathrm{L}$. The optimum $\mathrm{pH}$ range for hydrogen production for this process was observed in between 4.0 to 7 . This study indicates that rice mill wastewater can be successfully used for the production of hydrogen.
\end{abstract}

Keywords: Biohydrogen; Rice mill wastewater; Dark fermentation; Reducing sugar; $\mathrm{pH}$ control

\section{Introduction}

Today, most of the energy demands were met by non-renewable energy sources, resulting in resource depletion, environmental deterioration and public health problems. Therefore, a great demand is needed for novel renewable energy-harvesting technology for the sustainable development [1]. Hydrogen was expected to be the cleanest energy source of the future, since its sole product is water and it does not release $\mathrm{CO}_{2}$ and other harmful gases into the natural environment when it is used for energy production. Recently, great progress has been achieved in the technological development of fuel cells and in the storage and transportation of hydrogen [2]. Currently, hydrogen is produced by chemical, thermal and electrical processes, which are neither sustainable nor cost effective. Hydrogen production by biological methods is attractive because it is an energy saving production process compared with chemical process. Recently, fermentative hydrogen production has been reported to have great potential for development as a commercial biohydrogen production method [3].

Rice mill waste water is the starch rich and easily hydrolysable wastewater. When cultures were utilized in biohydrogen production, the reaction pathways and the resulting by-products can change unpredictably depending on the reactor conditions such as $\mathrm{pH}$, temperature and feedstock concentration as well as the nature of the microbial community. Moreover, most studies were performed under mesophilic condition $\left(35^{\circ} \mathrm{C}\right)$. Biohydrogen from dark fermentation can be conducted either by pure or mixed culture. For this study, fermentation was carried out by using only pure culture named as Enterobacter aerogenes [4-10] (Figure 1). Pretreatment of the waste has

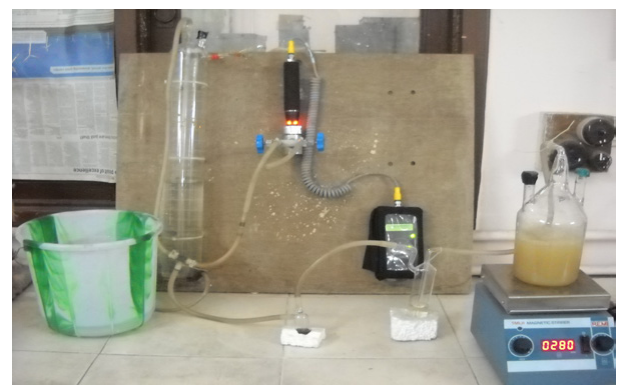

Figure 1: Experimental reactor setup-dark fermentation been investigated to eliminate or inhibit the non- $\mathrm{H}_{2}$ producing bacterial populations. The pretreatment of the waste has been approached with many methods, such as acid treatment, heat treatment and combined method [Heat + Acid]. In this study, an attempt was made to produce biohydrogen from rice mill wastewater $[11,12]$. Rice milling is the process of removing the husk and part of the bran from the paddy, in order to produce edible rice. Parboiled rice production requires large amounts of water for soaking the paddy. The amount of wastewater produced is about $1.0-1.2 \mathrm{~L} / \mathrm{kg}$ paddy (12) and this wastewater is rich in carbohydrates and is easily hydrolysable. It has a high chemical oxygen demand (COD), and is therefore suitable for anaerobic fermentation [13]. In this study, the acid was studied. The influence of operating parameters was studied to maximize the performance of different processes investigated [14,15] (Figures 2 and 3).

\section{Materials and Methods}

\section{Effluent}

The rice mill wastewater was collected from the local rice mill located in Kanchipuram, TN, India. The collected wastewater was subjected to sterilization in an autoclave at $121^{\circ} \mathrm{C}$ for $15 \mathrm{~min}$ to inactivate the non-sporogenic bacteria present in the wastewater. Then, the effluent was kept at $4^{\circ} \mathrm{C}$ until further use.

\section{Microorganisms}

E. aerogenes (MTCC2822) was obtained from Microbial Type Culture Selection (MTCC), India. It was incubated overnight in nutrient agar, [Hi-Media, India] at $35 \pm 2{ }^{\circ} \mathrm{C}$ under anaerobic condition. Prior, to cultivation, E. aerogenes, was activated by transforming a loop

"Corresponding author: Sundaram Haridoss, Department of Petroleum Engineering, AMET University, Chennai-603112, Tel: 0442747 2905; E-mail: sundaramharidoss@ametuniv.ac.in

Received November 29, 2016; Accepted December 24, 2016; Published December 30, 2016

Citation: Haridoss S (2016) Studies on Biohydrogen Production from Rice Mill Waste Water Using Enterobacter aerogenes MTCC 2822 by Dark Fermentation Process. J Pet Environ Biotechnol 7: 312. doi: 10.4172/2157-7463.1000312

Copyright: (c) 2016 Haridoss S. This is an open-access article distributed unde the terms of the Creative Commons Attribution License, which permits unrestricted use, distribution, and reproduction in any medium, provided the original author and source are credited. 


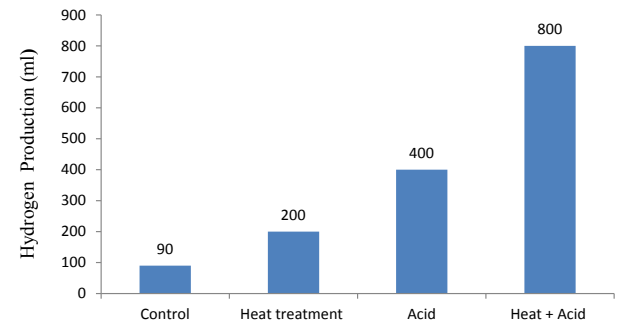

Figure 2: Comparison methods of pre-treatment of wastewater using Enterobacter aerogenes at temperature $35^{\circ} \mathrm{C}$.

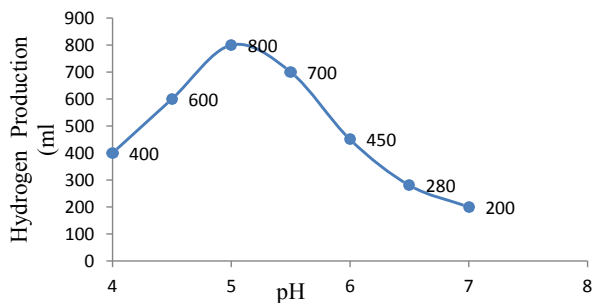

Figure 3: Effect of $\mathrm{pH}$ on hydrogen production using Enterobacter sp.

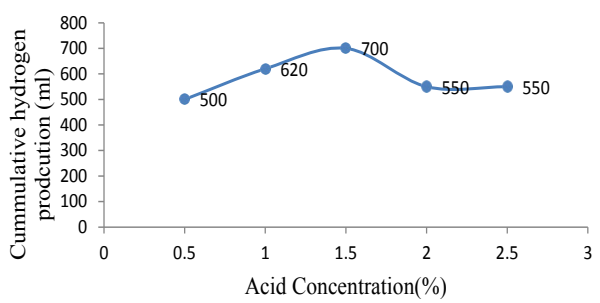

Figure 4: Effect of acid concentration on cumulative hydrogen production operating condtions: (Temperature $=35^{\circ} \mathrm{C}, \mathrm{pH}=5$ ).

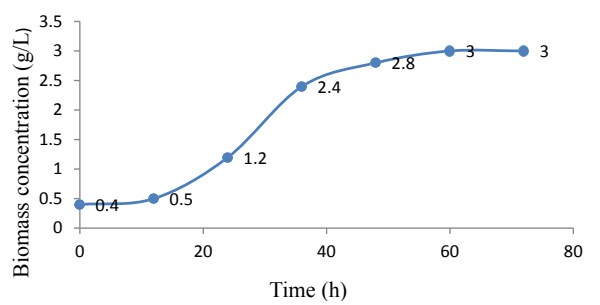

Figure 5: Effect of fermentation time on biomass production.

full of stock culture into $100 \mathrm{ml}$ of a sterile fresh synthetic medium ( $\mathrm{pH}$ 7.0) consisting of $2.0 \mathrm{~g} / \mathrm{L}$ of glucose, $1.0 \mathrm{~g} / \mathrm{L}$ of peptone, $0.05 \mathrm{~g} / \mathrm{L}$ of $\mathrm{MgSO}_{4} \cdot 7 \mathrm{H}_{2} \mathrm{O}, 0.1 \mathrm{~g} / \mathrm{L} \mathrm{KH}_{2} \mathrm{PO}_{4}$. The culture anaerobically incubated at $35 \pm 2^{\circ} \mathrm{C}$ for 24 hours at $150 \mathrm{rpm}$ in an orbital shaker.

\section{Acid hydrolysis}

Rice mill effluent of about $300 \mathrm{ml}$ was placed in an Erlenmeyer flask and $2 \mathrm{ml}$ of sulphuric acid was added to hydrolyze the sugars. The contents were autoclaved for $1 \mathrm{~h}$ until it reaches 15 Psia. Then, the effluent was fed into the reactor at $35^{\circ} \mathrm{C}$ under optimized conditions. The samples withdrawn at regular time intervals were centrifuged at $8000 \mathrm{rpm}$ for $15 \mathrm{~min}$. The supernatant obtained was subjected to sugar analysis.

\section{Experimental setup}

The anaerobic batch experiments were carried out in magnetically stirred $1000 \mathrm{ml}$ reactor with a working volume of $300 \mathrm{ml}$. The reactor was provided with a cork containing inlet for loading feedstock and bubbling nitrogen gas and also, an outlet nozzle for removing effluent and venting biogas. The reactor was placed on a magnetic stirrer for continuously stirring and maintains a constant temperature. The gas outlet was connected through Teflon tube to the liquid displacement system. Nitrogen gas was sparged into the reactor for $2-3$ min to create anaerobic environment prior to the seeding of the active anaerobic sludge. The influent was prepared using raw wastewater as the sole carbon source, supplemented with balanced nutrients and buffering chemicals. The $\mathrm{pH}$ of the mixed liquor in the reactor was adjusted using sulphuric acid and $\mathrm{NaOH}$ solutions. The batch reactor was routinely monitored for $\mathrm{pH}$ and gas production [16,17].

\section{Analytical methods}

The total biogas produced was measured by water displacement method. The hydrogen gas production was measured, using an online monitor ( $\mathrm{H}_{2} \mathrm{Scan}, \mathrm{HY}$-ALERTA, USA) [18]. The biomass concentration, $\mathrm{pH}$ and residual sugars were measured by following the standard methods [19]. Cell concentration was determined by centrifuging $2 \mathrm{ml}$ of culture broth at 10,000 to $12,000 \mathrm{rpm}$ for $15 \mathrm{~min}$. Cell pellets were washed twice with distilled water, dried at $105^{\circ} \mathrm{C}$ and the cell dry weight was determined [20-23].

\section{Results}

\section{Effect of pre-treatment on biohydrogen production}

The advantage of pre-treating the waste is inactivating non-sporing hydrogen consumers like methanogens and accelerating hydrogen producers like Enterobacter aerogenes. In the heat treatment process, the production of hydrogen mainly depends on the duration of the heat treatment of the waste (Figure 4).

\section{Effect of $\mathrm{pH}$ on hydrogen production}

In dark anaerobic fermentation, the control of $\mathrm{pH}$ is crucial to the hydrogen production, due to the effects of $\mathrm{pH}$ on the hydrogenase activity and on the metabolism pathways. In the present experiments, the effect of the initial ph of the medium on hydrogen production was investigated by varying the $\mathrm{pH}$ between 4 to 7 .

\section{Effect of acid concentration on hydrogen production}

The effect of acid concentration on cummulative hydrogen production is shown in Figure 4. The cummulative hydrogen production volume were increased with increase in the acid concentration and the maximum volume was observed at $1.5 \%$ acid concentration. After that, the cummulative hydrogen prodcuction has been decreased.

\section{Effect of fermentation time on biomass production}

During hydrogen production, the biomass of Enterobacter aerogenes has been increased with increase in the incubation time. The maximum biomass production rate obtained was $3.15 \mathrm{~g} / \mathrm{L}$. Initially the organism consumes the nutrients at the lag phase and the initial production of biomass concentration is very low (Figure 5).

\section{Effect of sugar utilization on hydrogen production}

During the fermentaion, the sugars present in the sample has been utilized by the microorgansim effectively and the total sugar content has been estimated to be $10 \%$. If the utilization is effective, the microorganism would be able to produce the hydrogen in effective manner (Figure 6). 


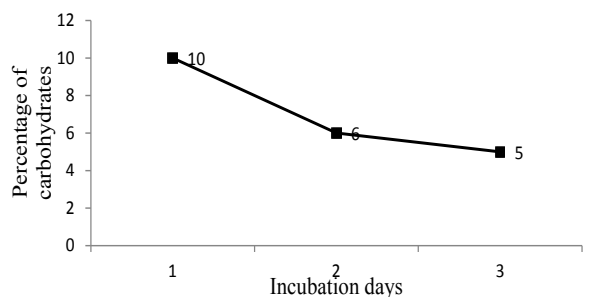

Figure 6: Effect of incubation time on sugar utilization.

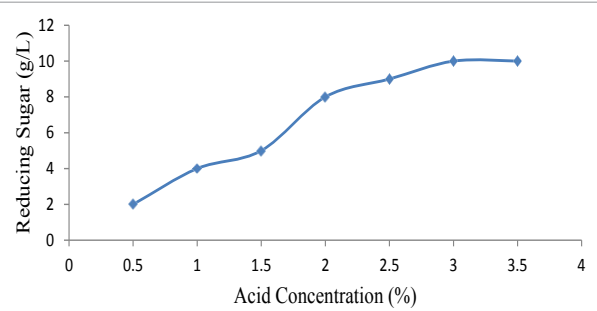

Figure 7: Effect of acid concentration on reducing sugar.

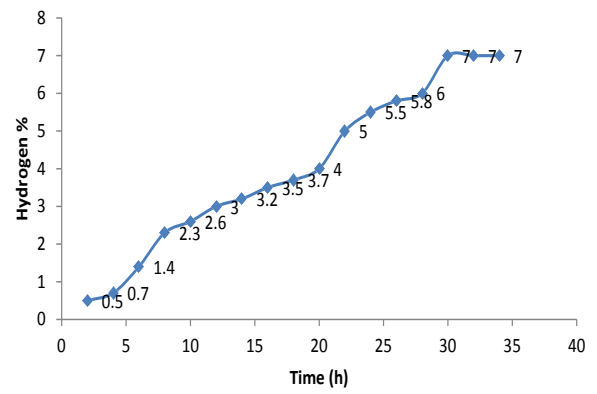

Figure 8: Effect of incubation time on hydrogen production using Enterobacter aerogenes operating conditions: (Temperature $=35^{\circ} \mathrm{C}, \mathrm{pH}=5$ ).

\begin{tabular}{|c|c|}
\hline $\mathbf{p H}$ & $\mathbf{4 . 4 8}$ \\
\hline Temperature & $35^{\circ} \mathrm{C}$ \\
\hline Total solids & $2 \mathrm{~g} / \mathrm{L}$ \\
\hline Biomass & $1 \mathrm{~g} / \mathrm{L}$ \\
\hline Total Carbohydrates & $16.75 \%$ \\
\hline
\end{tabular}

Table 1: Initial characteristics of rice mill effluent.

\begin{tabular}{|c|c|c|c|}
\hline Samples & $\mathbf{p H}$ & Total solids (g/L) & Total carbohydrates (\%) \\
\hline $\mathrm{S}_{1}$ & 4.33 & 2 & 10.02 \\
\hline $\mathrm{S}_{2}$ & 4.17 & 3.5 & 6.41 \\
\hline $\mathrm{S}_{3}$ & 8.56 & 116 & 4.97 \\
\hline
\end{tabular}

$\mathrm{S}_{1}$ - Day 1 sample, $\mathrm{S}_{2}$ - Day 2 sample, $\mathrm{S}_{3}$ - Third day sample

Table 2: Characterization after fermentation

\section{Effect of reducing sugar on different acid concentration}

Different acid concentration (\% v/v)were prepared to analyse the reducing sugar present in the wastewater. Initially the reducing sugar was $2.5 \mathrm{~g} / \mathrm{L}$ with acid concentration of $0.5 \%$ (Figure 7).

\section{Effect of Incubation time on hydrogen production}

The hydrolysate obtained from acid hydrolysis was subjected to fermentative hydrogen production. The effect of initial $\mathrm{pH}$ of rice mill wastewater on hydrogen production by $E$. aerogenes was investigated using the hydrolysate containing maximum reducing sugar obtained from acid hydrolysis (Figure 8). The $\mathrm{pH}$ was varied from 4.0 to 7.0 and ambient temperature was maintained $\left(35 \pm 2^{\circ} \mathrm{C}\right)$. The results showed that the hydrogen production was increased with an increase in the initial $\mathrm{pH}$ and better hydrogen production was observed in the $\mathrm{pH}$ range of $4.0-7.0$ [24-27].

\section{Discussion}

\section{Effect of pre-treatment on biohydrogen production}

From Figure 2, it was observed that the hydrogen production was $200 \mathrm{ml}$ and the when acid is added, the production was $800 \mathrm{ml}$. From this, it is clear that the hydrogen production by combined method (Heat + Acid $)$ is an improved and better way of hydrogen production.

\section{Effect of pH on hydrogen production}

As shown in the Figure 3, maximum hydrogen production of $800 \mathrm{ml}$ was observed at $\mathrm{pH}$ 5.0. This may be due to the suppression of methanogenic activity under acidic conditions. At higher or lower than this ph accumulation of acids causes a sharp drop of culture $\mathrm{pH}$ and subsequent inhibition of bacterial hydrogen production. Initial $\mathrm{pH}$ values of 4 to 7 were used in hydrogen fermentation by micro flora, which are believed to be suitable against methanogens in various fermentation systems.

\section{Effect of acid concentration on hydrogen production}

The reason for the effect of acid concentration on hydrogen production may be due to the degradation of the sugar molecules and the production of inhibitory compounds in the hydrolyzed medium.

\section{Effect of fermentation time on biomass production}

With increase in time, the microorganism consumes all the nutrients present in the substrate (rice mill effluent) and the maximum biomass concentration was observed at the stationary phase (Table 1).

\section{Effect of sugar utilization on hydrogen production}

The utilization of sugar by the microorganism is time consuming process, As the time increases, the sugars present in the wastewater has been reduced and the microbes cannot utilize it.

\section{Effect of reducing sugar on different acid concentration}

The maximum reducing sugar was $10.3 \mathrm{~g} / \mathrm{L}$ at a $3.5 \%(\mathrm{v} / \mathrm{v})$. From this, it was observed that the reducing sugar has been increased when the acid concentration increased.

\section{Effect of Incubation time on hydrogen production}

A lower/higher $\mathrm{pH}$ affected the hydrogen production negatively and this might be due to the inhibition of hydrogenase activity. The optimum $\mathrm{pH}$ range for the better hydrogen production was found to be $4.0-7.0$ It was observed that the maximum hydrogen production was $7.8 \%$ at 37 th $\mathrm{h}$ during five days of fermentation. For the first day two days, the production was very low and the microorganism consumed the substrate at third day (Table 2).

\section{Conclusion}

The results demonstrated the feasibility of $\mathrm{H}_{2}$ generation from rice mill wastewater using Enterobacter aerogenes. Mesophilic temperature showed positive influence on the hydrogen production and hydrogen yield at $30^{\circ} \mathrm{C}$. The optimum $\mathrm{pH}$ for hydrogen production was found to be 4 to 7 . The maximum reducing sugar was found to be $10.3 \mathrm{~g} / \mathrm{L}$ with acid concentration of $3.5 \% \mathrm{H}_{2} \mathrm{SO}_{4}$. Therefore, this study proved the feasibility of the fermentative biohydrogen production from rice mill effluent at mesophilic range by using facultative microorganism. 
Citation: Haridoss S (2016) Studies on Biohydrogen Production from Rice Mill Waste Water Using Enterobacter aerogenes MTCC 2822 by Dark Fermentation Process. J Pet Environ Biotechnol 7: 312. doi: 10.4172/2157-7463.1000312

\section{References}

1. Reungsg A, Sreela C (2013) Biohydrogen production from pineapple waste extract by anaerobic mixed cultures. Energies $6: 2175-2190$

2. Argun H, Kargi F, Kapdan IK, Oztekin R (2008) Batch dark fermentation of powdered wheat starch to hydrogen gas effects of the initial substrate and biomass concentrations. Int J Hydrogen Energy 33: 6109-6115.

3. Argun H, Kargi F (2009) Effects of sludge pre-treatment method on biohydrogen production by dark fermentation of waste ground wheat. Int $J$ Hydrogen Energy 34: 8543-8548.

4. Argun H, Kargi $F$ (2011) Bio-hydrogen production by different operational modes of dark and photo-fermentation: An overview. Int J Hydrogen Energy 36: $7443-7459$.

5. Arooj MF, Han SK, Kim SH, Kim DH, Shin HS (2008) Continuous biohydrogen production in a CSTR using starch as substrate. Int. J. Hydrogen Energy 2008 33: 3289-3294.

6. Cheng J, Zhang M, Song W, Xia A, Zhou J (2011) Cogeneration of hydrogen and methane from Arthrospira maxima biomass with bacteria domestication and enzymatic hydrolysis. Int J Hydrogen Energy 36: 1474-1481.

7. Fang HHP, Liu $\mathrm{H}$ (2002) Effect of $\mathrm{pH}$ on hydrogen production from glucose by a mixed culture. Bioresource Technol 82: 87-93.

8. Gadhamshetty V, Johnson D, Nirmalakhandan N, Smith G, Deng S (2009) Feasibility of biohydrogen production at low temperatures in unbuffered reactors. Int. J. Hydrogen Energy 34: 1233-1243.

9. Guo XM, Trably E, Latrille E, Carrere H, Steyer J (2010) Hydrogen production from agricultural waste by dark fermentation: A review. Int. J. Hydrogen Energy 2010, 35 (19), 10660-10673.

10. Han SK, Shin HS (2004) Biohydrogen production by anaerobic fermentation of food waste. Int. J. Hydrogen Energy 2004, 29, 569-577.

11. Kaushik N, Debabrata A (2003) Hydrogen from biomass. Curr. Sci 85: 265-271.

12. Koutrouli E, Kalfas H, Gavala H, Skiadas I, Stamatelatou K (2009) Hydrogen and methane production through two-stage mesophilic anaerobic digestion of olive pulp. Bioresource. Technol 100: 3718-3723.

13. Lay JJ, Lee YJ, Noike T (1999) Feasibility of biological hydrogen production from organic fraction of municipal solid waste. Water Res 33: 2579-2586.

14. Levin B, Pitt L, Love M (2004) Biohydrogen production: prospects and limitations to practical application. Int. J. Hydrogen Energy 29: 73-85.
15. Liu $\mathrm{H}$, Zhang $\mathrm{T}$, Fang HP (2003) Thermophilic $\mathrm{H} 2$ production from cellulose containing wastewater. Biotechnology. Lett 2003 25: 365-369.

16. Kumar N, Das D (2000) Enhancement of hydrogen production by Enterobacter cloacae IIT-BT 08. Process Biochemistry 35: 589-593.

17. Ogunfowokan AO, Fakankun OA (1998). Physicochemical characterization of effluents from beverage processing plants in Ibadan, Nigeria. Int. J Environmental studies 54: 145-152

18. Ohnishi A, Bando Y, Fujimoto N, Suzuki M (2010) Development of a simple bio-hydrogen production system through dark fermentation by using unique microflora. Int J Hydrogen Energy 35: 8544-8553.

19. Yang P, Zhang R, Mc Garvey J, Benemann J (2007) Biohydrogen production from cheese processing wastewater by anaerobic fermentation using mixed microbial communities. Int J Hydrogen Energy 32: 4761-4771

20. Pattra S, Sangyoka S, Boonmee M, Reungsang A (2008) Biohydrogen production from the fermentation of sugarcane bagasse hydrolysate by Clostridium butyricum. Int J Hydrogen Energy 33: 5256-5265

21. Rachman MA, Nakashinmada Y, Kakizono T, Nishio N (1998) Hydrogen production with high yield and high evolution rate by self-flocculated cells of Enterobacter aerogenes in a packed-bed reactor. Appl Microbial Biotechnology 49: $450-454$.

22. Shin HS, Youn JH, Kim SH (2004) Hydrogen production from food waste in anaerobic mesophilic and thermophilic acidogenesis. Int J Hydrogen Energy 29: $1355-1363$.

23. Sivaramakrishna D, Sreekanth D, Himabindu V, Lakshmi Narasu M (2010) Thermo-acidophilic biohydrogen production from rice bran de-oiled wastewate by selectively enriched mixed culture. Energy and Environment, 2010.

24. Su H, Cheng J, Zhou J, Song W, Cen K (2010) Hydrogen production from water hyacinth through dark- and photo fermentation. Int. J. Hydrogen Energy 35: 8929-8937.

25. Tanisho S, Kamiya N, Wakao N (1989) Hydrogen evolution of Enterobacter aerogenes depending on culture $\mathrm{pH}$ : mechanism of hydrogen evolution from $\mathrm{NADH}$ by means of membrane bound hydrogenase. Biochem Biophysics Acta 973: 1-6.

26. Wang CC, Chang CW, Chu CP, Lee DJ, Chang BV, et al. (2003) Producing hydrogen from wastewater sludge by Clostridum bifermentans. J. Biotechnology 102: 83-92.

27. Xing Y, Li Z, Fan Y, Hou H (2010) Biohydrogen production from dairy manures with acidification pre-treatment by anaerobic fermentation. Environ Sci Pollut Res Int 17: 392-399. 